\title{
The East Flanders Prospective Twin Survey (EFPTS)
}

\author{
Catherine A. Derom,' Robert F. Vlietinck,' Evert W. Thiery, ${ }^{2}$ Fernand O. G. Leroy, Jean-Pierre Fryns,' \\ and Robert M. Derom ${ }^{2}$ \\ ' Department of Human Genetics, Katholieke Universiteit Leuven, Leuven, Belgium \\ ${ }^{2}$ Association for Scientific Research in Multiple Births, Ghent, Belgium
}

\begin{abstract}
$T_{\text {is }}^{\text {h }}$ he East Flanders Prospective Twin Survey (EFPTS)

is a prospective, population-based registry of multiple births in the province of East Flanders, Belgium. EFPTS has several unique features: it is population based and prospective, with the possibility of longterm follow-up; the twins (and higher order multiple births) are ascertained at birth; basic perinatal data recorded; chorion type and zygosity established; and since 1969 placental biopsies have been taken and frozen at $-20{ }^{\circ} \mathrm{C}$ for later determination of genetic markers. The EFPTS is the only large register that includes placental data and allows differentiation of 3 subtypes of monozygotic (MZ) twins based on the time of the initial zygotic division: the dichorionicdiamnionic pairs (early, before the 4th day after fertilization), the monochorionic-diamnionic pairs (intermediate, between the 4th and the 7th day post fertilization), and the monochorionic-monoamnionic pairs (late, after the 8-day post fertilization). This added a new dimension to didymology (the science of twins; didymos is the Greek word for twin): the timing of $M Z$ twinning. Studies can be initiated taking into account primary biases, those originating in utero. Such studies could throw new light on the controversy over the validity of the classic twin method, the consequences of early embryological events (before and just after implantation of the embryo), the origin of congenital malformations, the sex proportion of multiples, the gene-environment interactions as far as intrauterine environment is concerned, to name but a few.
\end{abstract}

The East Flanders Prospective Twin Survey (EFPTS) was started in July 1964 at Ghent University, Department of Obstetrics, by Robert Derom and Michel Thiery, a twin himself. The founders became interested in twin surveys when one of them (RD), studying fetal oxygenation during labor, unexpectedly discovered that, as a rule, the second-born twin suffered from a low degree of intrauterine hypoxia (Derom, 1965). The survey was built according to the models of the Aberdeen twin studies (Davey \& MacGillivray, 1988) and the Birmingham Twin Survey (Cameron, 1968). In 1989, EFPTS moved to the Department of
Human Genetics of the University of Leuven (Belgium). At present it is hosted by Twins, a nonprofit Association for Scientific Research in Multiple Births. It is currently partly funded by the Department of Human Genetics of the University of Leuven, Twins, the University of Maastricht (Netherlands) and, since 2005, the Province of East Flanders.

The main aims of EFPTS are:

1. Determination of:

- the prevalence of multiple births in a well defined geographic area

- the number of mono-, di-, tri-, ... zygotic multiple births

- the number, nature and concordance of congenital malformations

- the obstetrical (duration of pregnancy, pregnancy and birth complications, birthweight, induction of ovulation and/or in vitro fertilization (IVF) and related techniques, placental weight, insertion of the cord, and so on) and obstetricopediatric outcomes (intrauterine growth, congenital malformations, perinatal and infant morbidity and mortality, and so on)

- other phenotypes on later age such as behavior, learning and school problems, intelligence, postnatal somatic growth, craniofacial growth, skeletal and dental maturation, sexual maturation, blood pressure, (sub)clinical depression and psychotic symptoms and so on

2. Investigation of:

- the causes of the multiple pregnancy

- the influence of zygosity and moment of zygotic division on the investigated traits

- the genetics of dizygotic (DZ) twinning

Received 8 July, 2006; accepted 18 August, 2006.

Address for correspondence: Dr C. Derom, Kwadenplasstraat 20, B-9070

Destelbergen, Belgium.E-mail: catherine.derom@uz.kuleuven.ac.be 
3. Use of improved methods of multiple birth studies for the determination of:

- the genetic predisposition of normal traits, diseases and malformations

- the role of the environment (with special emphasis on the prenatal environment) both individual-specific as well as common environmental influences

- the frequency and the importance of mirror-image twinning (Teplica \& Peekna, 2006).

\section{Subjects and Methods}

The inclusion criteria are the following:

- all the multiple maternities

- where one of the children weigh at least $500 \mathrm{~g}$ or, if birthweight is unknown, the gestational age is at least 22 weeks

- with birth in the Province of East Flanders (1,336,000 inhabitants; 14,500 births per year).

The specific methodology of this survey includes:

- determination of the zygosity of each multiple birth with near certainty to certainty through examination of the placental membranes and vascular anastomoses, blood groups and DNA-fingerprints (if necessary)

- the collection of medical data of the gynecologists and the neonatologist

- the follow-up of the multiple through one of the studies and/or questionnaires

- the establishment of a three-generation pedigree through civil birth registries.

Contact with the families of the multiples is maintained by:

- a biannual newsletter

- a TWIN hotline for the public and the parents of twins with psychological, educational, medical or practical problems. One psychologist backed by a team of physicians and specialists manage the telephone

- the organization of three general meetings per year and several specific meetings per year on subjects which most concern the parents such as language development, behavior and the development of individuality, schooling, educational problems, and so forth

- the organization of evening meetings where the parents of multiples just meet with each other and exchange experiences.

EFPTS and the Association for Scientific Research in Multiple Births (Twins) jointly provide these services to families with multiple births. Most of these services are carried out by volunteer workers.

\section{Table 1}

The Number of Twin Pairs in the EFPTS Born Between 1964-2005 by Zygosity, Chorion Type and Sex

\begin{tabular}{lccc}
\hline & \multicolumn{3}{c}{ Twins } \\
\hline Zygosity & Male-male & Female-female & Opposite-sexed \\
\hline Dizygotic & $1208(50 \%)$ & $1078(47 \%)$ & $2224(100 \%)$ \\
Monozygotic & & & \\
monochorionic & $766(31 \%)$ & $785(34 \%)$ & \\
Monozygotic & & & \\
dichorionic & $390(16 \%)$ & $395(17 \%)$ & \\
Unknown & $69(3 \%)$ & $58(2 \%)$ & \\
Total & $2433(100 \%)$ & $2316(100 \%)$ & $2224(100 \%)$ \\
\hline
\end{tabular}

Between 1964 and 2005, 6973 twin pairs, 214 triplets, 15 quadruplets, five quintuplets, and one octuplet were registered and investigated. Table 1 gives an overview of the registered twins according to the sex of the twin pairs and their zygosity and chorionicity. Presently, more than 3000 twin pairs have been enrolled in up to seven different studies. In some of these studies the parents and siblings of the twins were also examined.

\section{Results}

Some of the most important results are reported to illustrate the scope of our studies.

- Twin surveys are a valuable method in the study of malformations. In monozygotic (MZ) twin pairs most malformations are discordant (Cameron et al., 1983).

- A method to determine the zygosity of same-sexed twins, even macerated, through DNA-fingerprinting (Derom et al., 1985, 1991) and to calculate the probability of monozygosity in the same-sexed dichorionic (DC) twin pairs with the same blood groups (Meulepas et al., 1998) was developed.

- The MZ monochorionic-monoamnionic (MCMA) twin pairs (which split after the 8th day after fertilization) are predominantly female (Derom et al., 1988).

- The MZ monochorionic-diamnionic (MC-DA) twin pairs (which split after the 4th day after fertilization) have a higher mortality rate than DC MZ and $\mathrm{DZ}$ twin pairs. If the division takes place after the 8 th day, the mortality risk increases even more dramatically (Loos et al., 1998).

- After standardization for gestational age, the birthweight of twins is mainly determined by maternal factors especially the mother's genetic make-up, and to a lesser extent by the chorion type and the genes of the fetuses and their common environment (Vlietinck et al., 1989).

- Since the mid-1980s there has been a real explosion in the number of multiple births, primarily caused by the increasing administration of ovulation 


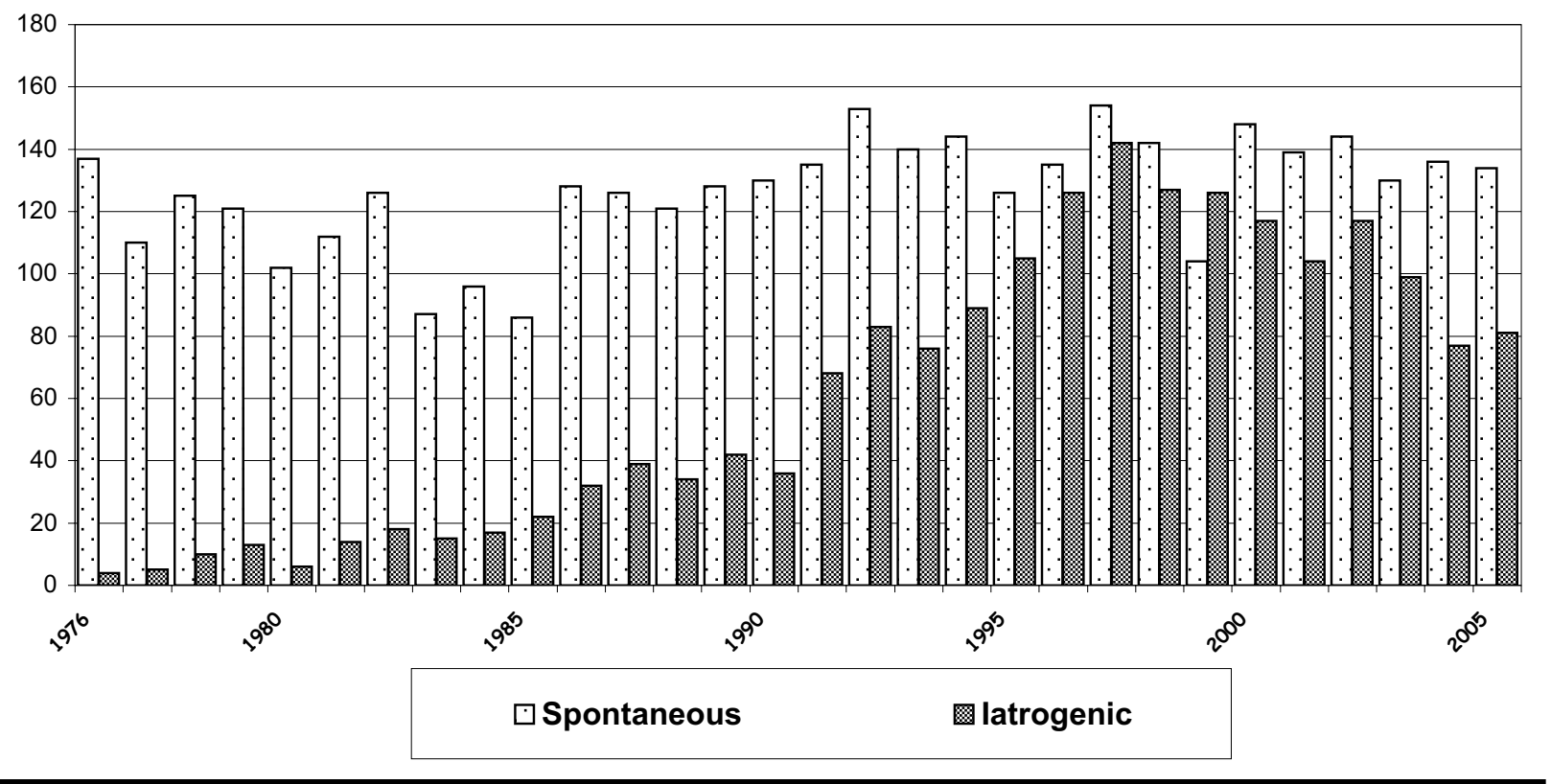

Figure 1

Yearly numbers of spontaneous and iatrogenic twin maternities: EFPTS 1976-2005.

stimulating agents and the use of other assisted reproduction techniques. We were the first to draw attention to the importance of this epidemic. This increase in the rate of multiple pregnancies represents an important public health problem because, if this trend continues, the rate of very preterm births and very low birthweight infants in the population will undoubtedly continue to rise (Figure 1; Derom et al., 1993). Recently there has been a steep decrease in the number of higher order multiple births and twins as a result of a selective feticide (selective abortion of one or more embryos or fetuses) policy and the single embryo transfer in IVF (Gerris, 2003). The frequency of zygotic splitting is higher after artificial induction of ovulation than after naturally occurring ovulation, which is of fundamental unexplained biological importance (Derom et al., 1987). Among iatrogenic MZ twins, the ratio of $M C$ versus DC pairs is higher compared with spontaneous twins. A greater proportion of MZ twins is observed with clomiphene citrate as sole treatment compared with other ovulatory drugs (Derom et al., 2006).

- The inheritance of spontaneous DZ twinning has been studied in collaboration with the Netherlands Twin Register (NTR) by segregation analysis of 1422 three-generation pedigrees; the parity-independent phenotype of 'having DZ twins' was consistent with an autosomal monogenic dominant model with a gene frequency of 0.035 and a female-specific lifetime penetrance of 0.10 (Meulemans et al., 1996). However, the results of a genome-wide scan of 14 Flemish families containing 57 mothers of spontaneous DZ twins gave suggestive evidence that the mode of inheritance of DZ twinning is probably more complex than was originally expected (Derom et al., 2006).

- The assumption that the division of the zygote occurs stepwise later in respectively DC-MZ, MCDA and MC-MA pairs has been recently demonstrated to be highly probable by studying Xinactivation within $M Z$ female pairs: $\mathrm{X}$-inactivation is totally symmetrical in MC-MA pairs, almost symmetrical in MC-DA pairs and asymmetrical in DC-MZ pairs (Chitnis et al., 1999; Monteiro et al., 1998; Puck, 1998).

- The belief that discordant handedness in MZ twins represents mirror-imaging is mythical: the often observed higher frequency of left-handedness in twins is confirmed but seems to be independent of zygosity and chorion type (Derom et al., 1996).

- A significant effect of chorion type on the heritability of two IQ-subtests was found: the MC twins resembled each other more than the DC-MZ twins on the subscales Arithmetic and Vocabulary. The effect accounts for respectively $14 \%$ and $10 \%$ of the total variance (Jacobs et al., 2001).

- Lower birthweight is a causal risk factor for child problem behavior, the effects of which may well extend into adulthood (Van Os et al., 2001; Wichers et al., 2001).

- In opposite-sexed twins the length of gestation and the birthweight of the male co-twin is influenced by his female co-twin and not the other way around (Loos, Derom, et al., 2001).

- An adverse prenatal environment during twin pregnancies has small, but permanent effects on health 
in adult life: adult body composition, blood pressure, glucose metabolism and renal function have part of their origins in utero, but they are programmed through different prenatal environmental influences. Furthermore, the prenatal environment seems to program men and women in a different way (Loos et al., 2001a, 2001b; Gielen et al., 2005).

- From early adolescence until young adulthood (10-18 years of age) static strength, explosive strength and the somatotype (Peeters et al., 2003) are under moderately strong genetic influence. Sex differences are significant from 14 years onwards. Genetic factors are the most important causes for the observed phenotypic stability in explosive strength (Peeters et al., 2005a), while for static strength, both genes and environment contribute to the phenotypic stability (Peeters et al., 2005b).

- Twins conceived through ovulation induction, IVF or intracellular sperm injection (ICSI) are at significantly elevated risk of preterm birth and, to lesser extent, of low birthweight. The observed risks associated with assisted reproduction are dampening down by predominantly DZ twinning following assisted reproduction and by differential maternal characteristics (Verstraelen et al., 2005).

- Stress-induced increase in negative affect regulates the individual sensitivity to small daily stress and is associated with elevated cortisol levels. This stress-induced increase in negative affect is influenced by genes, which is indicative for geneenvironment interaction. The serotonin transporter gene can be considered as the most attractive candidate gene (Jacobs, Kenis, et al., 2006; Jacobs, Rijsdijk, et al., 2006).

\section{$\overline{\text { Discussion }}$}

Criticism has been directed at classical twin studies with regard to the intrauterine environment of $\mathrm{MZ}$ twins. In an often quoted paper, Price (1950) reviewed the antenatal and natal difference-producing factors in MZ pairs. The most important of these is undoubtedly chorionicity. Other factors, however, must also be considered: zygosity, gestational age, birth sequence, birthweight, the origin of the pregnancy (iatrogenic or spontaneous), the mode of delivery and presentation of both twins (cephalic, breech, transverse). Price concludes:

It would seem to follow that part of the time and effort which will doubtless be expended on research with twins in the next decade or two could well be spent on identifying twin pregnancies two months or more before term, and obtaining much more complete information than we now possess as to the effects of prenatal and natal factors in the two types of $\mathrm{MZ}$ pairs. The results of such a study might show that the twin method, as ordinarily applied, is too crude for purposes of modern nature-nurture studies. At the same time, pairs of the MC type might prove to be of more interest and value for theoretical problems of developmental genetics than is commonly supposed.
Regrettably, Price's expectation has not materialized.

With a sizeable group of more than 780 DC-MZ and $1550 \mathrm{MC}-\mathrm{MZ}$ twin pairs the EFPTS can perform classic twin studies with no biases, that is, studies that are based on the crucial assumption that MZ and DZ twins have a similar intrauterine environment. Previous results have indicated that this could not be the case (Loos et al., 2001c; Phillips, 1993). Furthermore, comparison of DC-MZ, MC-MZ and DZ twins will allow the evaluation of the degree of gene-environment interaction in the prenatal environment. In contrast to all DC-MZ and DZ twins, MC-MZ twins share their chorion, their blood supply and therefore, their immune system during intrauterine life. This could have long-term effects on phenotypes in later life, as postulated by Phillips (1993) and Martin et al. (1997). As retrospective analysis of the placentation is still impossible to carry out, the effect of chorion type and mirror-imaging on phenotypes in later life will be one of the primary goals of EFPTS research. Another goal that requires special attention is the epigenetic phenomena, as MZ twins are a great tool for unraveling the importance of these effects.

Finally, with more than 1800 twins and triplets born after various techniques of assisted reproduction (ART), EFPTS is the ideal resource for the long-term follow-up study of these multiples on a population-based manner. As with recent reports suggesting increased rates of cerebral palsy among children born after IVF (Strömberg et al., 2002), these findings need to be validated in other population registers.

Although some aspects of the classical twin studies have been criticized, twin registries remain a wonderful resource for research. Large registries with subjects who are willing to participate in research and donate blood and tissue samples are great assets for future collaborations. Therefore one should focus on the development of a European multicentric, prospective and population-based registry of multiple births with accurate recording of placentation (chorionicity) and determination of zygosity.

\section{Acknowledgments}

Since its inception, EFPTS has been mainly and structurally supported by the Department of Obstetrics of the University of Ghent (Belgium), the Department of Human Genetics of the University of Leuven (Belgium), the University of Maastricht (the Netherlands) and more recently the Province of East Flanders. At present it is hosted in Twins, a nonprofit Association for Scientific Research in Multiple Births.

Research projects were aided by grants coming mainly from the Fund for Scientific Research Flanders, the Praeventiefonds (the Netherlands), the Dutch Foundation for Scientific Research, the Bertarelli Foundation and the Marguerite-Marie Delacroix Foundation. 


\section{References}

Cameron, A. H. (1968). The Birmingham twin survey. Proceedings of the Royal Society of Medicine, 61, 229-234.

Cameron, A. H., Edwards, J. H., Derom, R., Thiery, M., \& Boelart, R. (1983). The value of twin surveys in the study of malformations. European Journal of Obstetrics, Gynecology, and Reproductive Biology, 14, 347-356.

Chitnis, S., Derom, C., Vlietinck, R., Derom, R., Monteiro, J., \& Gregerson, P. (1999). X-chromosomeinactivation patterns confirm the late timing of monoamniotic-MZ twinning. American Journal of Human Genetics, 65, 571.

Davey, D. A., \& MacGillivray, I. (1988). The classification and definition of the hypertensive disorders of pregnancy. American Journal of Obstetrics and Gynecology, 158, 892-898.

Derom, C., Bakker, E., Vlietinck, R., Derom, R., Thiery, M., \& Pearson, P. (1985). Zygosity Determination in newborn twins using DNA variants. Journal of Medical Genetics, 22, 279-282.

Derom, C., Leroy, F., Vlietinck, R., Fryns, J. P., \& Derom, R. (2006). High frequency of iatrogenic monozygotic twins with administration of clomiphene citrate and a change in chorionicity. Fertility and Sterility, 85, $755-757$.

Derom, C., Maes, H., Derom, R., Van den Berghe, H., \& Vlietinck, R. (1993). Iatrogenic multiple pregnancies in East Flanders, Belgium. Fertility and Sterility, 60, 493-496.

Derom, C., Thiery, M., Vlietinck, R., Loos, R., \& Derom, R. (1996). Handedness in twins according to zygosity and chorion type: A preliminary report. Behavior Genetics, 26, 407-408.

Derom, C., Vlietinck, R., Derom, R., Boklage, C., Thiery, M., \& Van den Berghe, H. (1991). Genotyping macerated stillborn fetuses. American Journal of Obstetrics and Gynecology, 164, 797-800.

Derom, C., Vlietinck, R., Derom, R., Van den Berghe, H., \& Thiery, M. (1987). Increased monozygotic twinning rate after ovulation induction. Lancet, 1, 1236-1238.

Derom, C., Vlietinck, R., Derom, R., Van den Berghe, H., \& Thiery, M. (1988). Population-based study of sex proportion in monoamniotic twins. New England Journal of Medicine, 319, 119-120.

Derom, C., Jawaheer, D., Chen, W. V., McBride, K. L., Xiao, X., Amos, C., Gregersen, P. K., \& Vlietinck, R. (2006). Genome-wide linkage scan for spontaneous DZ twinning. European Journal of Human Genetics, 14, 117-122.

Derom, R. (1965). Anaerobic metabolism of the human fetus. II The twin delivery. American Journal of Obstetrics and Gynecology, 92, 555-562.

Gerris, J. (2003). Single embryo transfer - State of the art. Reproductive BioMedicine Online, 7, 615-622.
Gielen, M., Pinto-Sietsma, S. J., Zeegers, M. P., Loos, R. J., Fagard, R., de Leeuw, P. W., Beunen, G., Derom, C., \& Vlietinck, R. (2005). Birth weight and creatinine clearance in young adult twins: Influence of genetic, prenatal, and maternal Factors. Journal of the American Society of Nephrology, 16, 2471-2476.

Jacobs, N., Kenis, G., Peeters, F., Derom, C., Vlietinck, R., \& van Os, J. (2006). Stress-related affectivity and genetically altered 5-HTTT function: Evidence for synergism in shaping risk for depression. Archives of General Psychiatry, 63, 989-996.

Jacobs, N., Rijsdijk, F., Derom, C., Vlietinck, R., Delespaul, P., van Os, J., \& Myin-Germeys, I. (2006). Genes making one feel blue in the flow of daily life: A momentary assessment study of gene-stress interaction. Psychosomatic Medicine, 68, 201-206.

Jacobs, N., Van Gestel, S., Derom, C., Thiery, E., Derom, R., Vernon, P., \& Vlietinck, R. (2001). Heritability estimates of intelligence in twins: Effect of chorion type. Behavior Genetics, 31, 209-217.

Loos, R., Derom, C., Vlietinck, R., \& Derom, R. (1998). The East Flanders Prospective Twin Survey (Belgium): A population-based register. Twin Research, 1, 167-175.

Loos, R. J. F., Beunen, G., Fagard, R., Derom, C., \& Vlietinck, R. (2001a). Birth weight and body composition in young adult men: A prospective twin study. International Journal of Obesity and Related Metabolic Disorders, 25, 1537-1545.

Loos, R. J. F., Beunen, G., Fagard, R., Derom, C., \& Vlietinck, R. (2001b). The influence of zygosity and chorion type on fat distribution in young adult twins: Consequences for twin studies. Twin Research, 4, 356-364.

Loos, R. J. F., Beunen, G., Fagard, R., Derom, C., Vlietinck, R., \& Phillips, D. I. W. (2001c). Twin studies and estimates of heritability. Lancet, 357, 1445 .

Loos, R. J. F., Derom, C., Eeckels, R., Derom, R., \& Vlietinck, R. (2001). Length of gestation and birth weight in dizygotic twins. Lancet, 358, 560-561.

Martin, N., Boomsma, D., \& Machin, G. (1997). A twinpronged attack on complex traits. Nature Genetics, 17, 387-392.

Meulemans, W. J., Lewis, C. M., Boomsma, D., Derom, C., Van den Berghe, H., Orlebeke, J., Vlietinck, R., \& Derom, R. (1996). Genetic modelling of dizygotic twinning in pedigrees of spontaneous dizygotic twins. American Journal of Medical Genetics, 61, 258-263.

Meulepas, E., Vlietinck, R., \& Van den Berghe, H. (1998). The probability of dizygosity of phenotypically concordant twins. American Journal of Human Genetics, 43, 817-826.

Monteiro, V., Derom, C., Vlietinck, R., Kohn, N., Lesser, M., \& Gregerson, P. K. (1998). Commitment to Xinactivation precedes the twinning event in 
monochorionic MZ twins. American Journal of Human Genetics, 63, 339-346.

Peeters, M. W., Thomis, M. A., Claessens, A. L., Loos, R. J. F., Maes, H. H. M., Lysens, R., Vanden Eynde, B., Vlietinck, R., \& Beunen, G. P. (2003). Heritability of somatotype components from early adolescence into young adulthood: A multivariate analysis on a longitudinal twin study. Annals of Human Biology, 30, 402-418.

Peeters, M., Thomis, M., Maes, H., Loos, R., Claessens, A., Vlietinck, R., \& Beunen, G. (2005a). Genetic and environmental causes of tracking in explosive strength during adolescence. Behavior Genetics, 35, 551-563.

Peeters, M. W., Thomis, M. A., Maes, H. H. M., Beunen, G. P., Loos, R. J. F., Claessens, A. L., \& Vlietinck, R. (2005b). Genetic and environmental determination of tracking in static strength during adolescence. Journal of Applied Physiology, 99, 1317-1326.

Phillips, D. I. W. (1993). Twin studies in medical research: Can they tell us whether diseases are genetically determined? Lancet, 341, 1008-1009.

Price, B. (1950). Primary biases in twin studies. A review of prenatal and natal difference-producing factors in monozygotic pairs. American Journal of Human Genetics, 2, 293-352.

Puck, J. M. (1998). The timing of twinning: More insights from X-inactivation. American Journal of Human Genetics, 63, 327-328.
Strömberg, B., Dahlquist, G., Ericson, A., Finnström, O., Köster, M., \& Stjernqvist, K. (2002). Neurological sequelae in children born after in-vitro fertilisation: A population-based study. Lancet, 359, 461-465.

Teplica, D., \& Peekna, K. (2006). The mirror phenomenon in monozygotic twins. In I. Blickstein \& L. G. Keith (Eds.), Multiple pregnancy. Epidemiology, gestation and perinatal outcome (2nd ed., pp. 277-288). Oxon, UK: Taylor \& Francis.

Van Os, J., Wichers, M., Danckaerts, M., Van Gestel, S., Derom, C., \& Vlietinck, R. (2001). A prospective twin study of birth weight discordance and child problem behavior. Biological Psychiatry, 50, 593-599.

Verstraelen, H., Goetgeluk, S., Derom, C., Vansteelandt, S., Derom, R., Goetghebeur, E., \& Temmerman, M. (2005). Preterm birth in twins after subfertility treatment: Population based cohort study. British Medical Journal, 331, 1173-1177.

Vlietinck, R., Derom, R., Neale, M. C., Maes, H., Van Loon, H., Derom, C., \& Thiery, M. (1989). Genetic and environmental variation in the birth weight of twins. Behavior Genetics, 19, 151-161.

Wichers, M., Van Os, J., Danckaerts, M., Van Gestel, S., Derom, C., \& Vlietinck, R. (2001). Associations between nonshared environment and child problem behavior. Social Psychiatry and Psychiatric Epidemiology, 36, 319-323. 